\title{
POTENTIAL OF PYRETHRUM EXTRACT AGAINST LARVAL BIOCHEMISTRY OF RICE-MOTH, CORCYRA CEPHALONICA STAINT. (LEPIDOPTERA: PYRALIDAE)
}

\author{
S.K. Tiwari \\ Department of Zoology, D.D.U. Gorakhpur University, Gorakhpur - 273 009, India.
}

ABSTRACT: Sub lethal doses of pyrethrum extract caused a significantly dose dependent reduction in the levels of total protein, DNA, RNA, RNA/DNA ratio and a significantly dose dependent enhancement in total free amino acids in haemolymph and fat body tissues of the larva of rice-moth, C. cephalonica. $0.0004 \%$ dose level of this extract caused maximum effect on these biochemical parameters.

KEYWORDS: Pyrethrum extract, C. cephalonica, Haemolymph, Fat body, Biochemistry

\section{INTRODUCTION}

The rice-moth, Corcyra cephalonica (Staint.) is a notorious pest of stored cereals and cereal commodities in India as well as in other tropical and subtropical regions of the world. Its larval stages cause severe loss to rice, sorghum, currants, gram, milled products, cocoa beans, peanuts, cottonseed, linseed, raisins, chocolates, army biscuits and nutmeg ${ }^{3,38,2}$. Sufficient knowledge exists on the nutritional and reproductive physiology of this lepidopterous pest ${ }^{20,8}$, in addition to effects of insecticidal agents such as organochlorines, organophosphates, a few synthetic pyrethroids and botanical insecticides and a few IGRs on the development and larval biochemistry of $C$. cephalonica ${ }^{52,53,54,36,33,30,31,32,34,35,48}$.

The use of synthetic insecticides pose problems such as poisoning in man and other animals ${ }^{37}$, pest resistance to pesticides ${ }^{12}$, and the risk of contamination causing injury to non-target organisms and pollution to our own environment, thus disturbing the ecosystem. Hence there is an urgent need to develop safe alternatives to conventional insecticides for the protection of grain and grain products against insect infestations.

Pyrethrum is obtained from flowers of Chrysanthemum cinerariifolium harvested shortly after blooming, and either dried or powdered, or the oils within the flowers extracted with solvents. Pyrethrum extract is important in the control of household pests, in barns, stored products, and for direct application to man and livestock. It is generally considered to be the safest insecticide, and hence it has been selected as one of the safer substitutes to control Corcyra cephalonica in particular and lepidopterous pests in genral.

\section{MATERIALS \& METHODS}

A standard culture of C.cephalonica was maintained in the laboratory on normal dietary medium composed of coarsely ground jowar (Sorghum vulgare) mixed with 
$5 \%(\mathrm{w} / \mathrm{w})$ yeast powder inside glass containers $(150 \mathrm{~mm}$ diameter, $200 \mathrm{~mm}$ height) at $26 \pm 10 \mathrm{C}$ and $93 \pm 5 \%$ relative humidity.

Pyrethrum extract $23.3 \%$ (active ingredient) was purchased from SigmaAldrich, Steinheim, Germany (Lot. SZE7135X).

Preparation of different dose levels of pyrethrum extract in dietary media, evaluation of toxicity of different dose levels of pyrethrum extract, larval rearing and their treatment for biochemical estimation, separation and collection of haemolymph and fat body tissues has been done ${ }^{46}$. The entire programme of biochemical estimation includes the quantitative measurement of total protein, total free amino acid and nucleic acids in haemolymph and fat body of the larva of rice-moth treated with sublethal doses of pyrethrum extract as well as control.

The total protein was measured according to the method of Lowry et $\mathrm{al}^{24}$. using bovine serum albumin as standard while total free amino acid was estimated according to the method of Spies ${ }^{49}$ ) using glycine solution as standard.

Deoxyribonucleic acid (DNA) and ribonucleic acid (RNA) levels were estimated according to the method of Schneider ${ }^{43}$. Diphenylamine reagent was used for DNA estimation while orcinol reagent was used for RNA estimation.

\section{RESULTS AND DISCUSSION}

Changes induced by sublethal doses of pyrethrum extract on the levels of total protein and total free amino acids in haemolymph and fat body of the larva of Corcyra cephalonica have been represented in Table 1. Pyrethrum extract caused a dose dependent reduction in the level of total protein and an associated enhancement in the total free amino acid level in both the tissues of the larva (Table 1).

In control larval groups, the total protein content in the haemolymph and fat body was 68.879 and $12.886 \mu \mathrm{g} / \mathrm{mg}$ respectively. The maximum decrease in total protein level in haemolymph $(23 \%$ of the control value) and fat body (40\% of the control value) was observed in larvae treated with $0.0004 \%$ dose level of pyrethrum extract. Total protein levels, in haemolymph, were reduced to $74 \%(50.970 \mu \mathrm{g} / \mathrm{mg}), 55 \%$ $(37.883 \mu \mathrm{g} / \mathrm{mg})$ and $23 \%(15.842 \mu \mathrm{g} / \mathrm{mg})$ of the control value while these levels in fat body were reduced to $88 \%(11.340 \mu \mathrm{g} / \mathrm{mg})$, $57 \%(7.216 \mu \mathrm{g} / \mathrm{mg})$ and $40 \%(5.154 \mu \mathrm{g} / \mathrm{mg})$ of the control value following treatment with $0.0001 \%, 0.0002 \%$ and $0.0004 \%$ dose levels of pyrethrum extract respectively (Table 1).

The total free amino acid content, in the control larvae, was 88.580 and $11.729 \mu \mathrm{g} / \mathrm{mg}$ in haemolymph and fat body respectively. The maximum enhancement in the total free amino acid level in haemolymph ( $171 \%$ of the control value) and fat body ( $177 \%$ of the control value) was observed in larvae treated with $0.0004 \%$ 
dose level of pyrethrum extract. Total free amino acid levels, in haemolymph, were increased to $109 \%(96.552 \mu \mathrm{g} / \mathrm{mg}), 131 \%$ $(116.040 \mu \mathrm{g} / \mathrm{mg})$ and $171 \%(151.471 \mu \mathrm{g} / \mathrm{mg})$ of the control value while these levels, in fat body, were increased to $144 \%(16.890 \mu \mathrm{g} /$ $\mathrm{mg}), 161 \%(18.883 \mu \mathrm{g} / \mathrm{mg})$ and $177 \%$ $(20.760 \mu \mathrm{g} / \mathrm{mg})$ of the control value following treatment with $0.0001 \%, 0.0002$ $\%$ and $0.0004 \%$ of pyrethrum extract respectively (Table 1 ).

Table 1. Changes in the total protein and total free amino acid levels in the haemolymph and fat body of the larva of rice-moth, $C$. cephalonica treated with Pyrethrum extract

\begin{tabular}{|l|c|c|c|c|}
\hline \multirow{2}{*}{$\begin{array}{c}\text { Percent } \\
\text { pyrethrum } \\
\text { extract } \\
\text { concentration }\end{array}$} & \multicolumn{2}{|c|}{$\begin{array}{c}\text { Total protein } \\
(\mathrm{mg} / \mathrm{g} \text {. wet wt. })\end{array}$} & \multicolumn{2}{c|}{$\begin{array}{c}\text { Total free amino acid } \\
(\mu \mathrm{g} / \mathrm{mg}, \text { wet wt. })\end{array}$} \\
\cline { 2 - 5 } & Hamolymph & Fat body & Haemolymph & Fat body \\
\hline $\begin{array}{l}\text { Control } \\
\text { (untreated) }\end{array}$ & $\begin{array}{c}68.879 \pm 2.110 \\
(100)\end{array}$ & $\begin{array}{c}12.886 \pm 0.564 \\
(100)\end{array}$ & $\begin{array}{c}88.580 \pm 3.440 \\
(100)\end{array}$ & $\begin{array}{c}11.729 \pm 1.106 \\
(100)\end{array}$ \\
\hline 0.0001 & $\begin{array}{c}50.970 \pm 1.994 \\
(74)\end{array}$ & $\begin{array}{c}11.340 \pm 0.676 \\
(88)\end{array}$ & $\begin{array}{c}96.552 \pm 3.016 \\
(109)\end{array}$ & $\begin{array}{c}16.890 \pm 0.710 \\
(144)\end{array}$ \\
\hline 0.0002 & $\begin{array}{c}37.883 \pm 1.806 \\
(55)\end{array}$ & $\begin{array}{c}7.216 \pm 0.414 \\
(57)\end{array}$ & $\begin{array}{c}116.040 \pm 4.201 \\
(131)\end{array}$ & $\begin{array}{c}18.883 \pm 0.742 \\
(161)\end{array}$ \\
\hline 0.0004 & $\begin{array}{c}15.842 \pm 0.742 \\
(23)\end{array}$ & $\begin{array}{c}5.154 \pm 0.226 \\
(40)\end{array}$ & $\begin{array}{c}151.471 \pm 4.016 \\
(171)\end{array}$ & $\begin{array}{c}20.760 \pm 1.004 \\
(177)\end{array}$ \\
\hline
\end{tabular}

\# Values are expressed as the mean \pm s.e. of six replicates.

Values in the parentheses indicate the percentage change, with control values taken as $100 \%$.

Student's t-test showed significant differences $(\mathrm{P}<0.05$ to $\mathrm{P}<0.001)$ between the corresponding treated groups and the controls.

Analysis of variance showed that the response to the pyrethrum extract was dose dependent $\mathrm{P}<0.001$.

A dose dependent reduction in the levels of deoxyribonucleic acid and ribonucleic acid was recorded in haemolymph and fat body tissues of the larva following treatment with pyrethrum extract (Table 2).

In the control larval groups, the deoxyribonucleic acid level was 10.531 and $6.572 \mu \mathrm{g} / \mathrm{mg}$ in haemolymph and fat body respectively. The $0.0004 \%$ dose level of pyrethrum extract caused a maximum reduction in the level of DNA which was $51 \%$ in haemolymph and $41 \%$ in fat body with respect to their control values. DNA levels, in haemolymph, were reduced to $80 \%(8.425 \mu \mathrm{g} / \mathrm{mg}), 61 \%(6.424 \mu \mathrm{g} / \mathrm{mg})$, and $51 \%(5.371 \mu \mathrm{g} / \mathrm{mg})$ of the control value while these levels, in fat body, were reduced to $78 \%(5.126 \mu \mathrm{g} / \mathrm{mg}), 62 \%(4.075 \mu \mathrm{g} / \mathrm{mg})$ and $41 \%(2.695 \mu \mathrm{g} / \mathrm{mg})$ of the control value following treatment with $0.0001 \%, 0.0002 \%$ and $0.0004 \%$ dose level of pyrethrum 
extract respectively. It is also revealed that sublethal doses of pyrethrum extract caused a sharp reduction in DNA levels of fat body in comparison to those of haemolymph (Table 2).

The ribonucleic acid level, in control larvae, was 15.814 and $10.989 \mu \mathrm{g} /$ $\mathrm{mg}$ in haemolymph and fat body respectively. Larvae treated with $0.0004 \%$ dose level of pyrethrum extract showed a maximum reduction $(34 \%$ in haemolymph and $32 \%$ in fat body of their control values) in the level of RNA. RNA levels, in haemolymph, were reduced to $79 \%$ $(12.493 \mu \mathrm{g} / \mathrm{mg}), 55 \%(8.698 \mu \mathrm{g} / \mathrm{mg})$ and $34 \%$ $(5.377 \mu \mathrm{g} / \mathrm{mg})$ of the control value while these levels, in fat body, were decreased to $75 \%(8.242 \mu \mathrm{g} / \mathrm{mg}), 54 \%(5.934 \mu \mathrm{g} / \mathrm{mg})$ and $32 \%(3.516 \mu \mathrm{g} / \mathrm{mg})$ of the control value following treatment with $0.0001 \%, 0.0002 \%$ and $0.0004 \%$ dose levels of pyrethrum extract respectively (Table 2 ).

Table 2. Changes in the DNA and RNA levels in the haemolymph and fat body of the larva of rice-moth, $C$. cephalonica treated with Pyrethrum extract

\begin{tabular}{|l|c|c|c|c|}
\hline \multirow{2}{*}{$\begin{array}{c}\text { Percent } \\
\text { pyrethrum } \\
\text { extract } \\
\text { concentration }\end{array}$} & \multicolumn{2}{|c|}{$\begin{array}{c}\text { DNA }^{\#} \\
(\mathrm{mg} / \mathrm{g} \text {. wet wt. })\end{array}$} & \multicolumn{2}{c|}{$\begin{array}{c}\mathrm{RNA}^{\#} \\
(\mu \mathrm{g} / \mathrm{mg}, \text { wet wt. })\end{array}$} \\
\cline { 2 - 5 } & Hamolymph & Fat body & Haemolymph & Fat body \\
\hline $\begin{array}{l}\text { Control } \\
\text { (untreated) }\end{array}$ & $\begin{array}{c}10.531 \pm 0.441 \\
(100)\end{array}$ & $\begin{array}{c}6.572 \pm 0.411 \\
(100)\end{array}$ & $\begin{array}{c}15.814 \pm 0.612 \\
(100)\end{array}$ & $\begin{array}{c}10.989 \pm 0.401 \\
(100)\end{array}$ \\
\hline 0.0001 & $\begin{array}{c}8.425 \pm 0.467 \\
(80)\end{array}$ & $\begin{array}{c}5.126 \pm 0.369 \\
(78)\end{array}$ & $\begin{array}{c}12.493 \pm 0.565 \\
(79)\end{array}$ & $\begin{array}{c}8.242 \pm 0.364 \\
(75)\end{array}$ \\
\hline 0.0002 & $\begin{array}{c}6.424 \pm 0.411 \\
(61)\end{array}$ & $\begin{array}{c}4.075 \pm 0.255 \\
(62)\end{array}$ & $\begin{array}{c}8.698 \pm 0.511 \\
(55)\end{array}$ & $\begin{array}{c}5.934 \pm 0.312 \\
(54)\end{array}$ \\
\hline 0.0004 & $5.371 \pm 0.402$ & $\begin{array}{c}2.695 \pm 0.211 \\
(41)\end{array}$ & $\begin{array}{c}5.377 \pm 0.301 \\
(34)\end{array}$ & $\begin{array}{c}3.516 \pm 0.214 \\
(32)\end{array}$ \\
\hline
\end{tabular}

\# Values are expressed as the mean \pm s.e. of six replicates.

Values in the parentheses indicate the percentage change, with control values taken as $100 \%$. Student's t-test showed significant differences $(\mathrm{P}<0.05$ to $\mathrm{P}<0.001)$ between the corresponding treated groups and the controls.

Analysis of variance showed that the response to the pyrethrum extract was dose dependent $\quad \mathrm{P}<0.01$.

Sub lethal doses of pyrethrum extract caused a dose dependent reduction in RNA/DNA ratio in both the tissues of the larva. In control larvae, the RNA/DNA ratio, which is an index of the protein synthetic capacity per cell, was 1.502 and
1.658 in haemolymph and fat body respectively. The maximum decrease in this ratio in haemolymph $(67 \%$ of the control value) and fat body (79\% of the control value) was observed in larvae treated with $0.0004 \%$ dose level of pyrethrum extract. 
RNA/DNA ratios, in haemolymph, were reduced to $99 \%(1.483 \mu \mathrm{g} / \mathrm{mg}), 90 \%(1.354$ $\mu \mathrm{g} / \mathrm{mg})$ and $67 \%(1.001 \mu \mathrm{g} / \mathrm{mg})$ of the control value while these values, in fat body, were reduced to $97 \%(1.608 \mu \mathrm{g} / \mathrm{mg}), 88 \%$
$(1.456 \mu \mathrm{g} / \mathrm{mg})$ and $79 \%(1.305 \mu \mathrm{g} / \mathrm{mg})$ of the control value following treatment with $0.0001 \%, 0.0002 \%$ and $0.0004 \%$ dose levels of pyrethrum extract respectively (Table 3 ).

Table 3. Alterations in the RNA/DNA ratio in haemolymph and fat body of the larva of rice-moth, C. cephalonica treated with Pyrethrum extract

\begin{tabular}{|l|c|c|}
\hline \multirow{3}{*}{$\begin{array}{c}\text { Percent } \\
\text { pyrethrum } \\
\text { extract } \\
\text { concentration }\end{array}$} & \multicolumn{2}{|c|}{$\begin{array}{c}\text { RNA / DNA ratio } \\
\text { (mg/g. wet wt.) }\end{array}$} \\
\cline { 2 - 3 } & Hamolymph & Fat body \\
\hline Control & 1.502 & 1.658 \\
(untreated) & $(100)$ & $(100)$ \\
\hline 0.0001 & 1.483 & 1.608 \\
& $(99)$ & $(97)$ \\
\hline 0.0002 & 1.354 & 1.456 \\
& $(90)$ & $(88)$ \\
\hline 0.0004 & 1.001 & 1.305 \\
& $(67)$ & $(79)$ \\
\hline
\end{tabular}

The values in the parentheses indicate the percentage change, with control value taken as $100 \%$.

The present investigation, reveals Pyrethrum extract (a biopesticides) induced changes in the levels of total protein, total free amino acid, DNA, RNA, and RNA/ DNA ratio in the haemolymph and fat body tissues of the larva, pertaining to a specific age group, of the rice-moth, Corcyra cephalonica. The findings are discussed here in the light of the insecticidal influence of pyrethrum extract on the basic extrinsic as well as intrinsic cellular mechanisms such as transport, synthesis, degradation and storage in relation to the aforesaid biochemical constituents to come to some such conclusions which may in future help in divising ways and means for the effective control of this lepidopterous pest.

Studies, regarding mode of action of botanicals, have revealed that active ingredients present in the insecticidal plants inhibit some of the enzyme systems and subsequent mortality ${ }^{13,21,29,40}$. Active ingredients of leaves of Calotropis and Ipomea have been reported to inhibit some of the enzyme systems and subsequent mortality ${ }^{21,29}$. Active ingredients of Ocimum had also been known to act as a reversible competitive inhibitor of acetyl cholinesterase $^{40}$ like azadirachtin, abundantly present in the neem seeds that 
have been shown to inhibit the release of prothoracicotropic hormones and allatropins ${ }^{4}$, thereby affecting metamorphosis in insect $^{42}$ is well documented.

Active compounds of Pyrethrum extract have a quick knock down effect against insects. They act on tiny channels through which sodium is pumped to cause excitation of neurons. They prevent sodium channels from closing resulting in continual nerve impulse transmission, tremors, and eventually death. Thus, it may be concluded that pyrethrum extract, in the present investigation, disturbs the permeability of sodium across the nerve membrane causing body convulsions which ultimately leads to death.

Proteins are among the most complex of all known chemical compounds and also the most characteristic of living organism. They serve as an important internal environmental factor for the metabolism, especially having a close relation with fat body, metamorphic hormone, trehalose and sex hormone during development and metamorphosis ${ }^{23}$. Protein synthesized in the early instars of the larval fat body (the main site of protein synthesis of blood protein) are subsequently released into the surrounding blood ${ }^{45}$, which, in later instars are sequestered from the blood into the fat body. Regarding their synthesis ${ }^{47}$ in Drosophila amino acids are first incorporated into peptides and later enter into proteins ${ }^{56}$.

In the present investigation, all the three sublethal doses of Pyrethrum extract (Table 1) caused a significant dose dependent $(\mathrm{P}<0.001)$ reduction in the level of total protein in both the tissues of the larva. Earlier investigations have revealed that botanical insecticides (natural plant products / biopesticides) influence the biochemistry of insect pests. Application of Annona squamosa seed extracts caused a significant reduction in protein content in the nymphs of Dysdercus koenigii ${ }^{7}$. In a similar way, azadirachtin ${ }^{50}$ has also been reported to cause significant alteration in protein contents in certain other insects. The present results are also in agreement with findings of above workers. Synthetic insecticides have also been shown to decrease the total protein level in insects by inhibiting amino acid incorporation into protein causing adverse effect on protein biosynthesis $^{25,23,1}$.

Protein synthesis in the insect fat body is also inharently regulated by endocrine secretions. â-ecdysone stimulated the protein synthesis (in vitro) in the larval fat body of Calliphora stygia ${ }^{28}$ and á- ecdysone stimulated the same in oak worm Antheraea pernyi $^{41}$. Similarly, juvenile hormone enhanced the rate of protein synthesis in larval fat body of the milkweed bug Oncopeltus fasciatus ${ }^{5}$. Thus, it may be concluded that these plant insecticides might affect the endocrine secretion in addition to amino acid incorporation into protein, resulting into poor protein biosynthesis which ultimately leads to reduced level of protein in haemolymph as well as in fat 
body.

One of the most characteristic features of insect haemolymph is the high level of free amino acids ${ }^{11,17,18,57,15,14,16}$ whereas insect fat body is an active site for the intermediary metabolism of these amino acids ${ }^{19,14}$. The high concentration of free amino acid is believed to play an important role in osmoregulation $^{9,6}$ buffering of the blood to some extent, energy production for flight and cocoon construction ${ }^{57}$ with the predominant function of serving as units for protein synthesis ${ }^{11}$ and taking part in other metabolic activities.

In the present investigation, all the three sublethal doses of pyrethrum extract (Table 1) caused a significantly dose dependent $(\mathrm{P}<0.001)$ enhancement in the level of total free amino acids in both the tissues of the larva. Reddy et al. (1993) have reported that active compounds extracted from seed of Annona squamosa has enhanced the amino acid content in Dysdercus koenigii possibly due to this biopesticide induced depletion of protein and / or inhibition of amino acid incorporation into protein ${ }^{39}$. Similarly, botanical insecticides have been reported to induc alterations in the free amino acid contents of Spodoptera litura ${ }^{55}$. Thus, in the present investigation, it may be concluded that a rise in the total free amino acid level in both the tissues of the larva is plausibly on account of protein depletion and / or inhibition of amino acid incorporations in to protein.

RNA content can be considered an index of the capacity of organism for protein synthesis where as DNA content provides an estimate of cell number. The RNA / DNA ratio is, therefore, a measure of protein synthetic capacity per cell ${ }^{10,22}$. Literatures concerning botanical insecticides and pyrethroid induced changes in the nucleic acid levels with special reference to insects $^{27,51}$ are far from adequate.

In the present investigation, all the three sublethal doses of pyrethrum extract (Table 2) caused a significantly dose dependent $(\mathrm{P}<0.01)$ reduction in the levels of DNA and RNA and a significant reduction in RNA / DNA ratio (Table 3) in both the tissues of the larva of this pest. Botanicals (neem compounds) and pyrethroid have been shown to inhibit the nucleic acid level in Musca domestica L. ${ }^{26}$. Similar findings have also been observed in case of pulse beetle, Callosobruchus analis ${ }^{51}$ L. following treatment with neem compounds NfC (Neutral fraction C- which is a crude extract of whole neem seed) and NC (Nimocilin, Azadirachtin). But, sublethal and lethal doses of fenpropathrin (a pyrethroid) did not change much of the RNA and DNA levels in the larvae of Tribolium castaneum (Herbst.) ${ }^{44}$.

The reduction in the DNA and RNA levels, in the present study, may be due to interference of pyrethrum extract with the synthesis site of nucleic acids. This finding is in accordance with Tabassum, (1994) who reported similar possibility of the decreased DNA and RNA due to the action of neem compounds NfC and NC (Nimocilin, 
Azadirachtin) on nucleic acids synthesis in the exposed pulse beetle, Callosobruchus analis (L.) ${ }^{51}$. Similar explanation for decrease in DNA and RNA contents have also been reported in fenpropathrin exposed larvae of Tribolium castaneum (Herbst.) ${ }^{44}$. As stated earlier, the two parameters- RNA content and RNA / DNA ratio, show a significant correlation with protein content. Thus, the protein content depends on its synthesis in which RNA plays a vital role. Data in the present study also demonstrate the reduction in the total protein level in both the tissues of the larva following treatment with pyrethrum extract. Therefore, it may be presumed that the synthesis of protein is inhibited due to inhibition of RNA. It may also be presumed that reduction in protein level is due to the involvement of pyrethrum extract in influencing the transport of amino acids as well as their incorporation into the polypeptide chain. The enhancement in total free amino acid level further supports the above presumption.

On the basis of overall findings, in the present investigation, it may be concluded that pyrethrum extract disrupts the metabolic framework of the larva hence, evolution of a new generation of this pest for the eventual establishment on stored cereals and cereal products can be considerably restricted.

\section{ACKNOWLEDGEMENT}

Author is highly thankful to SigmaAldrich, Germany for providing Pyrethrum extract (Lot.SZE7135X) 23.3\% (a. i.).

\section{REFERENCES}

1. Agosin, M., L. Aravena and A. Neghme, 1965. Enhanced protein synthesis in Triatoma

2. Allotey, J., 1991. Development and fecundity of the rice-moth, Corcyra cephalonica (Pyralidae). Discovery \& Innovation 3: 123126

3. Atwal, A.S., 1976. Agricultural pests of India and South East Asia. Kalyani Publishers, Delhi. pp.502.

4. Banken, J.A.Q. and J. Stark, 1997. Stage and age influence on the susceptibility of Coccinella septempunctata after direct exposure to Neemex, a neem insecticide. $J$. Econ. Entomol., 90: 1102-1105.

5. Bassi, S.D. and D. Fleir, 1971. Effects of juvenile hormone on the rates of protein synthesis in Oncopeltus fasciatus. Insect. Biochem., I: 428-32.

6. Beadle, L. and J. Shaw, 1950. The retention of salt and the regulation of the NPN fraction in the blood of the aquatic larva, Sialia lutaria. J. exp. Biol., 127: 96-109.

7. Bhagawan, C.N., K.D. Reddy and K. Sukumar, 1992. Annona-induced growth anomalies and protein depletion in red cotton bud Dysdercus koenigii. Indian J. Exp. Biol., 30: 908-912.

8. Bhatt RS and S.S. Krishna, 1982. Changes in the content of some biochemical components during development of eggs of the rice-moth, Corcyra cephalonica (Staint.). Zoological Magazine 31: 70-73

9. Bishop, G.H., A.P. Briggs and E. Ronzoni, 1926. Body fluids of honey bee larva. J. Biol. Chem., 66: 77-88.

10. Brachet, J., 1955. In: The Nucleic Acids. Vol. II, Academic Press, New York.

11. Buck, J.B., 1953. The internal environment in regulation and metamorphosis. In: Insect Physiology Ed.: K. Roeder. Wiley, New York, 191-217.

12. Chand, R. \& S.P. Birthal, 1997. Pesticide use in Indian agriculture in relation to growth in area of production and technological change. 
Indian Journal of Agricultural Economics 52(3): 488-498

13. Chaterjee, A. and S.C. Prakashi, 1995. Calotropis procera In: The treatise on Indian Medicinal plants, Publication and Information Directorate, New Delhi, pp. 130.

14. Chen, P.S., 1966. Amino acid and protein metabolism in insect development. In: Advances in Insect Physiology. Beament J.W.L., J.E. Treherne and V.B. Wigglesworth (eds). 3: 53-132. Academic Press, New York.

15. Clements, A.M., 1963. The Physiology of Mosquitoes. Pergamon Press, Oxoford.

16. Florkin, M. and C. Jeuniaux, 1974. Haemolymph: Composition. In: Rockstein, M. (ed.). The physiology of insects. 5: 255307. Academic Press, New York.

17. Florkin, M., 1959. The free amino acids of Insect haemolymph. Proc. VIth int. Cong. Biochem., 12: $63-73$

18. Gilmour, D., 1965. The metabolism of Insects. Oliver \& Boyd, Edinburg. pp. 115-147.

19. Kilby, B.A., 1963. The biochemistry of the insect fat body. In: Advances in Insect Physiology, (Beament, J.W.L., J.E. Treherne and V.B. Wigglesworth eds.)., 1: 111-174. Academic Press, London and New York.

20. Krishna, S.S. and A.S. Narain, 1976. Ovipositional programming in the rice-moth, Corcyra cephalonica (Staint.) (Lepidoptera: Galleridae) in relation to certain extrinsic and intrinsic caues. Proc. Indian natu. Sci. Acad., B 42: 325-332.

21. Kuroyanagi, M., T. Arakawa, Y. Hirayama and T. Hayashi, 1999. Antibacterial and antiandrogen flavonoids from Sophora flavescens. J. Nat. Prod., 62: 1595-1599.

22. Lang, C.A., H.Y. Lau and D.J. Jefferson, 1965. Protein and nucleic acid changes during growth and aging in the mosquito. Biochem. J., 95: 372-7.

23. Lee, J.J., J.C. Shim and K.R. Lee, 1981. The effect of insecticides on haemolymph in the German cockroach, Blattela germanica L.
The Korean J. of Entomol. Vol. XI, No. I, pp. 25-32.

24. Lowry, O.H., N.J. Rosenbrough, A.L. Farr and R.J. Randall, 1951. Protein measurement with the Folin phenol reagent. J. Biol. Chem., 193: 265-275.

25. Molchanov, M.I., F.S. Kuteev., V.A. Molchanova and V.V. Nikiforov, 1980. The influence of organophosphorus insecticides on proteins in the haemolymph of gypsy moth (Porthetria dispar) caterpillars. Appl. Biochem. Microbiol. (Engl. Transl. Prikl. Biochim. Microbiol), 16(5): 548-554.

26. Naqvi, S.N.H., K. Akhtar and M.A. Azami, 1991a. Toxicity of NfD against Sitophilus oryzae L. exposed to impregnated filter paper and its effects on phosphatases and protein metabolites. Acta Biologica. Crac. Zoolgia Ser., X X X III: pp. 49-58.

27. Naqvi, S.N.H., S.M. Nurulain and R. Tabassum, 1991b. Effect of neem fraction and pyrethroid on the nucleic acid of Musca domestica L. Proc. Ist Nat. Biochem. Symp. pp. 21.

28. Neufeld, G.J., A.J. Thomson and D.S. Horn, 1968. Short term effects of crust ecdysone (20-hydroxy ecdysone) on protein and RNA synthesis in third instar larvae of Calliphora . J. Insect . Physiol., 14:789-804.

29. Padmavati M. and A.R. Reddy, 1999. Flavonoid biosynthetic pathway and cereal defense response: An emerging trend in crop biotechnology. J. Plant Biochem. Biotechnol., 8:15-20.

30. Pathak, C.S. and S.K. Tiwari, 2012. Insecticidal action of neem seed (Azadirachta indica A. Juss) acetone extract against the life-cycle stages of rice-moth, Corcyra cephalonica (Staint.) (Lepidoptera: Pyralidae). World J. Agric. Sci., 8(5): 529-536.

31. Pathak, C.S. and S.K. Tiwari, 2015a. Toxicity of Bioresmethrin on the Developmental Stages and Larval Biochemistry of RiceMoth, Corcyra cephalonica Staint, (Lepidoptera: Pyralidae). I.J.Z.I., 1(1):55-71.

32. Pathak, C.S. and S.K. Tiwari, 2015b. Toxicity 
of neem stem bark powder against the ontogeny of rice moth, Corcyra cephalonica Staint, (Lepidoptera: Pyralidae). I.J.Z.I., 1(2): 187-191, 2015.

33. Pathak, C.S. and S.K. Tiwari, 2010b. Toxicological effects of neem, Azadirachta indica A. Juss leaf powder against the ontogeny of Corcyra cephalonica (Staint.) (Lepidoptera: Pyralidae). Journal of Biopesticides, 3(3): 617-621.

34. Pathak, C.S. and S.K. Tiwari, 2016. Potential of neem stem bark powder against the larval biochemistry of rice moth, C. cephalonica Staint (Lepidoptera: Pyralidae) I.J.Z.I., 2(2): 304-323.

35. Pathak, C.S. and S.K. Tiwari, 2017. Potential of neem seed's acetone extracts on the haemolymph and fat body biochemistry of rice moth, Corcyra cephalonica Staint (Lepidoptera: Pyralidae) J. Adv. Zool., 38(2):164-177.

36. Pathak, C.S. and S.K. Tiwari (2010a) Toxicity of neem seed (Azadirachta indica A. Juss, Meliaceae) extract against the immature stages of rice-moth, Corcyra cephalonica (Staint.) (Lepidoptera: Pyralidae). Journal of Applied Bioscience, 36(2): 173-177.

37. Pichaet, W. and J.R.B. Philogene, 1993. A natural path to pesticides. IDRC Reports (Canadian Collaboration for development). 21(2).

38. Piltz, H., 1977. Corcyra cephalonica (Staint.) In J. Kranz. (Schmutterer H. and Koch W.) (eds.,) Disease pests and weeds tropical crops. Verlag Paul Parey, Berlin and Hamburg. pp. 439-440.

39. Reddy, K.D., C.N. Bhagawan and K. Sukumar, 1993. Depletion of amino acids and protein in the nymphal haemolymph of the red cotton bug, Dysdercus koenigii (Fab.) (Hemiptera: Pyrrhocoridae) treated with Annona squamosa extract Phytophaga, 5: 45-50.

40. Ryan, M.R. and O. Byrne, 1988. Plant-insects coevolution and inhibition of acetylcholine esterase. J. Chem. Ecol., 14: 1965-1975.
41. Sahota, T.S. and A. Mansingh, 1970. Cellular responces to ecdysone : RNA and protein synthesis in larval tissues of Oakworm, Autheraea pernyi. J. Insect. Physiol., 16: 1649-54.

42. Schmutterer, H. and H. Rembold, 1995. Neem tree-source of unique natural products for integrated pest management, medicine industry and other purposes (ed. Schmutterer, H.), VCH, Weinheim, Germany.

43. Schneider, W.C., 1957. Determination of Nucleic Acids in tissues by Pentose Analysis. In: Methods in Enzymology. Colowick, S.P. and N.O. Kaplan (eds), Academic Press, New York, pp 680-684.

44. Shakoori, A.R., M. Fayyaz and M.A. Saleem, 1988. Biochemical changes induced by fenpropathrin in the $6^{\text {th }}$ instar larvae of Tribolium castaneum (Herbst.) (Coleoptera: Tenebrionidae). J. Stord. Prod. Res., 24: 215220.

45. Shigematsu, H., 1960. Protein metabolism in the fat body of the silk worm, Bombyx mori L. Bull. Seric. Exp. Sta., Japan, 16: 141-70.

46. Shukla, S. and S.K. Tiwari, 2011. Studies on the effect of certain natural plant products on the chemistry of haemolymph and fat body of the larva of rice-moth, Corcyra cephalonica Stainton. (Lepidoptera: Pyralidae). Ph.D. Thesis, Dept. of Zoology, Gorakhpur Univ. Gorakhpur, U.P. India.

47. Simmons, J.R. and H.K. Mitchell, 1962. Metabolism of peptides in Drosophila. In "Amino acid pools", J.T. Holden (ed.) pp. 147-155. Elsevier, Amsterdam.

48. Singh, A. and S.K. Tiwari, 2014. physiological and biochemical effects of fenoxycarb, a juvenile hormone analogue on rice moth, corcyra cephalonica staint (lepidoptera : pyralidae), Ph.D. Thesis, Dept. of Zoology, Gorakhpur Univ. Gorakhpur, U.P. India.

49. Spies, J.R., 1957. Colorimetric procedures for amino acids. In: Methods in Enzymology. Colowick, S.P. and N.O. Kaplan (eds.), Academic Press, New York, pp: 464-471. 
50. Subramanyam, B.E. and P.J. Rao, 1986. Curr. Sci., 55(11): 534 .

51. Tabassum, R., 1994. Toxicity and residual effect of some neem compound (Nimocinol etc.) in comparision with IGR (Dimilin) against stored grain pests. Ph. D. Thesis, Dept. of Zoology, University of Karachi, Pakistan.

52. Tiwari, S.K. and R.S. Bhatt, (1999a). Effect of barthrin on the developmental stages of ricemoth, Corcyra cephalonica (Staint.) (Lepidoptera: Pyralidae) Journal of Advanced Zoology 20 (2): 103-105.

53. Tiwari, S.K. and R.S. Bhatt (1999b). Cypermethrin and fenvalerate induced toxicity against ontogeny of rice-moth, Corcyra cephalonica. Bulletin of Life Science, 9: 19-24.
54. Tiwari, S.K. and C.P.M. Tripathi, 2006. Tetramethrin induced toxicity against the ontogeny of rice-moth, Corcyra cephalonica (Staint.) (Lepidoptera: Pyralidae). Uttar Pradesh Journal of Zoology, 26(2): 227-229.

55. Vijayaraghavan, C. and K.C. Chitra, 2002. Total protein and free amino acid content of Spodoptera litura (Fabr.) due to botanicals and conventional insecticides. Indian J. of Entomology, 64: 92-95.

56. Weinmann, H.P., 1964. Untersuchungen mit markierten Aminosauren Zum Proteinstoffwechsel normaler und letaler Genotype von Drosophila melanogaster, Z. Vergl. Physiol., 48: 429-461.

57. Wyatt, G.R., 1961. The biochemistry of insect haemolymph. A. Rev. Ent., 6:72-102. 